\title{
Knowledge and Perception of Parents Towards Diet in Children with Autism
}

\author{
Ade Rosi, Chandra Isabella Hostanida Purba, Sri Hartati Pratiwi \\ Faculty of Nursing, Universitas Padjadjaran \\ Email: aderosi49@gmail.com
}

\begin{abstract}
Gluten Free Casein Free (GFCF) is a diet recommendation to reduce hyperactivity in children with autism. Lack of adherence and knowledge can lead to improper dietary application which will result in remaining health problems and hyperactive behavior of autistic children. The purpose of this study is to examine knowledge and perception of parents towards GFCF diet in children with autism. This descriptive-quantitative study used a total sampling technique to 57 parents of autistic children in 3 Bandung District Extraordinary Schools. Data was obtained through questionnaire with validity ranging from $0.315-0.912$ and reliability of 0.788 and 0.932 . Data was analyzed using frequency and percentage in descriptive statistics. Results showed that some parents lacked of knowledge $(n=28)$, and $67 \%$ of subjects $(n=38)$ had a positive perception of GFCF diet. Positive perception includes perception of benefits, perception of susceptibility, perception of self efficacy, and perception of severity. In the perception of barrier, some subjects had negative perception. Based on the results, several parents had positive perception of GFCF diet, although the parental knowledge related to this diet was in the low category. That is likely because of parents have not received sufficient information related to GFCF diet. Therefore, health workers especially community nurses are expected to collaborate with nutritionists in making regular visits in order to provide parents of autistic children with health education related to GFCF diet in extraordinary schools.
\end{abstract}

Keywords : Autism, Gluten Free Casein Free diet, Knowledge, Perception. 
Ade Rosi: Knowledge and Perception of Parents Towards Diet in Children with Autism

\section{Indtroduction}

Autism or Autism Spectrum Disorder (ASD) is a pervasive development disorder that is usually found from infancy to preschool age (before three years of age). The most common signs of this disorder include impaired communication, disruption of social interactions, interests, behavioral patterns, limited and repetitive activities (stereotypes), and tend to close themselves and have their own world (Greene, Rathus, \& Beverly, 2003). The incidence of autism continues to increase, both at global and local levels. At the global level the incidence reaches 7.6 million sufferers or 1 per 160 children identified as having autism (Centers for Disease Control and Prevention, 2015). The number of autistic people in Indonesia have not been identified, but the cases are estimated to increase. This is based on the number of patient visits in public hospitals, and in child development clinics (Ministry of Health of the Republic of Indonesia, 2012). Data from the West Java Provincial Education Office (2010) recorded about 599 autistic children spread throughout the SLB (a school for disabilities) West Java Province, and in 2018 this number increased to 1532 children. Bandung Regency has the highest number of autistic children compared to Bandung City, which is 304 people.

Many theories explain that autism occurs due to gene mutations, neurological disorders, and biology. Whiteley et al., (2013) stated that biological problems in autistic children occur due to digestive disorders. A research has been carried out by Ratnawati in 2013 found that about $60 \%$ of autistic patients have an imperfect digestive system, including the presence of leaky gut syndrome or the appearance of small holes in the intestinal mucosa. This situation results in the production of digestive enzymes from the pancreas that are used to break down peptide proteins are inhibited, and resulting in the breakdown of incomplete peptide proteins. This type of protein peptide is found in foods and drinks that contain gluten and casein.

Gluten and casein are part of short-chain amino acids commonly called peptides. According to Whiteley et al., (2010) in normal conditions, peptide is only slightly absorbed by the body and is mostly discharged through feces. However, in people with autism it does not happen, some of the peptides are absorbed into the blood circulation and some are towards the brain. The peptide leading to the brain attaches to the opioid receptor and changes its function like morphine. Opioid peptides that attach to the brain of an autistic child will affect the central nervous system so that influence the cognitive abilities, speech ability, pain threshold disorders, sleep disorders and cause behavioral disorders such as more hyperactive. The hiperactive is not only movements but also emotions such as anger or go berserk (Fadhli, 2010; Murdiyanta, Ramani, \& Sulistiyani, 2015; Nugraheni, 2008). It can be concluded that gluten and casein cause some behavioral disorders in autistic children. Therefore, autistic children are encouraged to go on a GFCF diet (Gluten Free Casein Free).

GFCF diet is a therapy that is carried out by removing food sources containing gluten and casein proteins, parents are not allowed to give, and serve foods that contain gluten and casein. Food containing gluten is found in wheat products and food containing casein found in animal milk products (Marí-Bauset, Llopis-González, Zazpe, Marí-Sanchis, \& Suárez-Varela, 2016). Kawicka and Regulska-Ilow (2011) mention the GFCF diet is a food therapy that is processed directly in the body. If done with other therapies, such as behavior therapy, speech therapy, and physical occupational therapy, it will have a better effect on autistic children.

Parents are one of factors that greatly influence the implementation of the GFCF diet (Koka, 2011). This is because the diet in autistic children is inseparable from the role of parents in providing and conducting good and nutritious. Parents do food supervision according to their children's needs. So, their children food will be fulfilled if parents understand the condition of children with autism. Parents' understanding of the GFCF diet have an impact on the success of therapy. The negative impact that will arise if parents do not implement the GFCF diet properly and obediently, it will cause a buildup of opioid peptides in the brain of autistic children so that there is an increase in hyperactive behavior, and children become difficult to develop (Hurwitz, 2013). From the results 
Ade Rosi: Knowledge and Perception of Parents Towards Diet in Children with Autism

of these studies it can be concluded that parental compliance has an important role in increasing the effectiveness of the GFCF diet.

Sofia et. al.'s (2012) study at the SLB of Cileunyi State and Pelita Hafizh Bandung Foundation showed that parents' compliance with autistic children in implementing the GFCF diet was still very low at only $15 \%$. The results of the study were reinforced by the research of Rahmah, Diani, and Rachmawati (2015) in Banjarmasin which showed that parents who adhered to the GFCF diet were only $29.03 \%$ (Rahmah, Diani, \& Rachmawati, 2015; Sofia, 2012). The low compliance of parents must be addressed immediately. However, before overcoming adherence, knowledge of what factors influence parental compliance in implementing GFCF diet therapy is needed. The Health Belief Model (HBM) theory states that factors that influence behavior include a person's adherence to carrying out therapy, namely perceptions and cues to action. Glanz, Rimer, \& Viswanath (2008) explain that the most fundamental factor in carrying out an action or behavior is perception. Perception will influence the effectiveness of certain treatments in autistic children, whether parents will continue treatment or stop it (Bowker, D'Angelo, Hicks, \& Wells, 2011). The components of perception related to obedience according to Stretcher \& Rosenstock (1997, in Glanz et al., 2008) include perceptions of vulnerability to the risks posed, perceptions of the severity of an illness, perceptions of benefits, and barriers, and perceptions of self efficacy.

Perception is influenced by several factors, including age, gender, knowledge, and economic income (Glanz, Rimer, \& Viswanath, 2015). From these factors, the component that would be changed someone perception is knowledge (Efendi, 2014). Solish \& Perry (2008) stated that high parental knowledge of interventions for autistic children would increase parental involvement in therapy significantly. Especially GFCF diet therapy, parents play a role in regulating, giving and serving food for autistic children. Therefore, to support the application of the correct GFCF diet in autistic children, good knowledge is needed about the GFCF diet, so that mothers have understanding in choosing and making food. It can be concluded that knowledge and perception play an important role in decision making, therapy selection and also fundamental behaviors for therapy compliance.

The researcher has conducted a preliminary study at the SLB of Cileunyi Bandung, BC Multahada SLB, and SLB Satria Galdin by interviewing 5 parents of autistic children and also teachers in the SLB. The five parents of autistic children said they did not know about the gluten and casein diet, after mentioning the flour and milk diet, parents said they knew. They've tried the diet, but it's not obedient because of various reasons. Some of them said that the price of food products with free gluten and casein are expensive, another reason autistic children to eat any foods, parents cannot bear if children with autism are given many restrictions. In addition, the school environment does not support the implementation of the GFCF diet. It can be seen from the number of snacks that contain gluten and casein which are sold in the school. The teacher at the SLB also stated that parents did not implement the GFCF diet. This can be seen from the snacks of autistic children which are mostly sourced from flour such as fried foods, wheat and milk.

The explanation encouraged researchers to conduct research on parents' knowledge and perceptions of the GFCF diet in autistic children. After knowing the level of knowledge and perceptions of parents about the GFCF diet, it is expected to be the basic data of health education by community nursing to increase parental participation in implementing the GFCF diet. This study aimed to describe the knowledge and perceptions of parents regarding Gluten Free Casein Free (GFCF) diets in autistic children.

\section{Research Method}

This research is a quantitative descriptive with cross sectional approach, researchers were conducted data collection simultaneously without follow-up (Nursalam, 2013). The population in this study was 57 parents of autistic students in 3 Bandung District SLB. The sampling technique was the total sampling. Questionnaire developed from Murdiyanta et al (2015) research 
Ade Rosi: Knowledge and Perception of Parents Towards Diet in Children with Autism

that developed instruments on factors that influence mothers in food selection in autistic children, and Mutianingrum (2013) regarding the relationship between maternal knowledge and giving gluten-free diet and casein, and nutritional status of autistic children. The components instrument are the definition of GFCF diet, the benefits of a gluten free casein free diet, and types of foods that contain gluten and casein. The instrument used to measure parents' perceptions of a gluten free casein free diet was a closed questionnaire using a statement with a Likert scale. The perception questionnaire was created and adapted from concept of the Health Belief Model (HBM) by Glanz et al (2008) as well as the concept of the GFCF diet by Whiteley et al (2010). The components of perception that are measured including perception of vulnerability, perception of severity, perception of benefits, perception of barriers, and perceptions of self-efficacy.

Validity testing is done through a test of content validity and construct validity. The results of validity test in the knowledge questionnaire have a correlation coefficient value between $0.371-0.871$. The perception questionnaire is between 0.315-0.912. This range of values shows that each item statement representing each variable is declared valid because it has a validity coefficient value above 0.30 (Sugiyono, 2010). The reliability test results on knowledge instruments were 0.788 and in the perceptual instruments were 0.932 , so the research instruments were declared reliable. Data analysis used descriptive statistics in the form of frequency and percentage. The level of knowledge devided into three criteria including good when $75 \%$ answer is correct ,moderate with 56-74\% correct answer, and insufficient knowledge if the correct answer is $<55 \%$ (Arikunto, 2006 in Budiman \& Riyanto, 2013). The study result was presented in table form. This research has ethical permission from the Health Research Ethics Commission, Faculty of Medicine, Padjadjaran University with the number: 348 / UN6.KEP / EC / 2018.

\section{Research Results}

Table 1 Characteristic respondent $(n=57)$

\begin{tabular}{lcc}
\hline \multicolumn{1}{c}{ Characteristic Respondent } & Frequency (f) & Percentase (\%) \\
\hline Sex & 25 & 44 \\
Male & 32 & 56 \\
Female & & \\
Age & 18 & 31 \\
Early Adult (18-40) & 38 & 67 \\
Middle Age (40-60) & 1 & 2 \\
Elderly (>60) & & \\
GFCF Diet Information & 40 & 70 \\
Yes & 17 & 30 \\
No & & \\
Information Sources & 4 & 7 \\
Book & 1 & 2 \\
Internet & 35 & 61 \\
Health Professionals & & \\
\hline
\end{tabular}

Table 2 Respondents' knowledge of GFCF $\operatorname{diet}(\mathbf{n}=\mathbf{5 7})$

\begin{tabular}{|c|c|c|}
\hline Category & Frequency (f) & Percentase $(\%)$ \\
\hline Good & 14 & 25 \\
\hline Moderate & 15 & 26 \\
\hline Insufficient & 28 & 49 \\
\hline
\end{tabular}


Ade Rosi: Knowledge and Perception of Parents Towards Diet in Children with Autism

Table 3 Parents' perception of Gluten Free Casein Free diet $(n=57)$

\begin{tabular}{ccc}
\hline Category & Frequency (f) & Percentase (\%) \\
\hline Positif & 38 & 6 \\
Negatif & 19 & 33 \\
\hline
\end{tabular}

Table 4 Parents' Perception of Gluten Free Casein Free Diet in Autistic Children (n=57)

\begin{tabular}{ccccc}
\hline Domain & \multicolumn{2}{c}{ Positive } & \multicolumn{3}{c}{ Negative } \\
\cline { 2 - 5 } & f & \% & f & \% \\
\hline $\begin{array}{c}\text { Perception of } \\
\text { Benefits }\end{array}$ & 50 & 88 & 7 & 12 \\
$\begin{array}{l}\text { Vulnerability } \\
\text { Perception }\end{array}$ & 44 & 77 & 13 & 23 \\
$\begin{array}{c}\text { Perception of Self } \\
\text { Efficacy }\end{array}$ & 39 & 68 & 18 & 32 \\
$\begin{array}{c}\text { Perception of } \\
\text { Severity }\end{array}$ & 32 & 56 & 25 & 44 \\
$\begin{array}{c}\text { Perception of } \\
\text { Obstacles }\end{array}$ & 27 & 47 & 30 & 53 \\
\hline
\end{tabular}

Table 1 present that teh majority of responden $(56 \%)$ were female, middle age (40-60) 38 respondents $(67 \%)$. The majority had glutean and casein information $70 \%$, and the information source was health professionals $(61 \%)$.

Some respondents had insufficient knowledge about gluten-free and casein-free diets as many as 28 people $(49 \%)$.

The majority of parents had positive perceptions of gluten-free and casein diet 38 people $(67 \%)$.

The majority of respondents had a positive perception providing Gluten Free Casein Free diet for autistic children 50 people $(88 \%)$, vulnerability perceptions 44 people $(77 \%)$, perceptions of self efficacy 39 people $(68 \%)$, and perceptions of severity 32 people $(56 \%)$. In the perception of obstacles some respondents had a negative perception $(53 \%)$. of applying the GFCF diet.

\section{Discussion}

The results of research showed that some respondents had insufficient knowledge of GFCF diet. It may because of information obtained by parents regarding the GFCF diet is incomplete. The preliminary study also found that the school and parents also stated that they had never attended a socialization program from health workers about the
GFCF diet. Parents only received information regarding the GFCF diet once when they were initially diagnosed by a doctor without any further explanation of how to administer the GFCF diet properly. The information provided is also limited, there is no twoway communication between health workers and parents. Parents had limited knowledge about foods that should be avoided by autistic children including flour and milk. This is consistent with Norouzi's statement in Sadeghi (2014) that giving information by the lecture method has the disadvantage that participants become inactive, one direction of communication, and participants forget the material presented quickly.

Other factors that may cause limited knowledge parents regarding the GFCF diet are parents' awareness of in seeking information (Sofia, 2012). The results showed that only a few parents sought information through books and the internet. Notoatmodjo (2012) explains that information is one of the things that can affect one's knowledge because information has an influence on the individual who subsequently results in change and increase in knowledge. The more information obtained, the wider the knowledge.

Social support can also influence parents' knowledge regarding the GFCF diet. The results of the study showed that parents stated that the school environment did not 
Ade Rosi: Knowledge and Perception of Parents Towards Diet in Children with Autism

support the implementation of the GFCF diet, even facilitating foods containing gluten and casein in their canteens. In addition, the majority of respondents stated that they did not provide the GFCF diet at home. According to McKinley and Wright (2014) social support increases someone to search information through internet sites, and facilitate consumers for a healthy diet. Therefore, lack of social support from the surrounding environment can influence parents to seek information regarding the GFCF diet.

Insufficient knowledge of the GFCF diet has an impact on providing improper food for children. This is in accordance with the Mutianingrum (2013) study which shows that a good level of mother's knowledge is in line with the implementation of a gluten-free diet and casein correctly and vice versa. Improper GFCF diet practices cause health problems in autistic children such as decreased bone density and slow bone growth (Hurwitz, 2013; Marí-Bauset et al., 2016). Therefore, good knowledge regarding the GFCF diet is important for parents. Health education is carried out to increase parents' knowledge.

The results showed that the majority of respondents received health education, but there were respondents who had a lack of knowledge. Steiner, Koegel, Koegel, and Ence (2012) state that educational programs for parents with autistic children would do in group or individual. The majority of respondents were in the middle age category, so it may influence the ability to receive information (Mubarak, Cahyatin, Rozikin, and Supradi, 2007). Health education is carried out using effective media, for example videos and leaflets so parents could read the material at home (Steiner et al, 2012). Videos and leaflets help parents who do not attend health education programs.

The results showed the overall perceptions of respondents regarding the GFCF diet in a positive category. These results indicate that parents understand the importance of glutenfree diets and casein for their children. The majority of respondents in the study were mothers, where the main roles of mothers in family, are as the primary caregiver who has greater responsibility for caring for autistic children, when they practising the GFCF diet so that the hyperactive behavior of children have decrease (Sari \& Sari, 2015). This positive perception is formed when the mother sees the symptoms of her child's improvement because they avoid to eat foods that contain gluten and casein. However, it cannot guarantee the full involvement of the mother in the GFCF diet program as they may have high barriers.

The components of benefits that are perceived positively include a decrease in hyperactive behavior, more focus, no worsening of symptoms, and no weakness. However, a small proportion of respondents did not feel the benefits of the GFCF diet, respondents stated that the GFCF diet worsened the symptoms of autism, and made their children weak, perhaps because of the experience of parents practicing improper GFCF diets (Apriana, 2016). Although in general the GFCF diet eliminates foods containing gluten and casein protein but the nutrition of children must remain balanced. This is in accordance with the research of Niland and Cash (2018) that someone who applies a gluten-free diet is at risk of nutritional imbalance or even malnutrition because gluten-free products have a doubling of protein reduction. Therefore, the GFCF diet must be balanced with nutrient-dense foods such as carbohydrates, fiber, folate, iron, and kalisum.

The results showed that most respondents had a positive perception of vulnerability if they did not apply the GFCF diet to autistic children. The perceived of vulnerability includes symptoms in children with autism does not experience a decline, is at risk of experiencing sleep disorders, and causes the development of their children obstructed. Parents did not adhere to the GFCF diet obediently. This is in line with the Carpenter study in 2010, which stated that perceived vulnerability is not always a predictor of preventive behavior, it can be seen from how far the problem experienced affects his life. So that the perception of vulnerability experienced by parents does not make him go on a strict diet, possibly because of the vulnerability that is felt not to affect the lives of parents of children with autism, and lack of knowledge causes parents not to know how the GFCF diet affects their children. 
Ade Rosi: Knowledge and Perception of Parents Towards Diet in Children with Autism

Most respondents have positive self-efficacy. Positive perceptions of self-efficacy indicate that parents have the confidence to practise a GFCF diet in autistic children. This perceived belief includes self-confidence when food for children is free of gluten and casein, make sure to tell other family members not to feed their children carelessly, and is confident that they can pass all obstacles in carrying out a gluten-free and casein diet. But most parents feel unsure about applying the GFCF diet to their children because they don't know how to do it properly. The low self efficacy to practise the diet properly may because of parents are never gotten knowledge about how to implement the correct GFCF diet. This is supported by the statement of Artino (2012), that good knowledge is the basis for someone to take appropriate actions.

Perception of severity also showed positive results. The perceived severity is having the feeling that the child's hyperactive behavior cannot be controlled when consuming foods containing gluten and casein, the severity also felt by the respondents affected their children's social relations. Based on HBM theory according to Glanz et al (2008), one of the factors that a person will commit to health behavior, including the perceived that a treatment will have an impact on one's health. Feelings of worry or even threatening arise from the perception that individuals are vulnerable to health problems and those problems can have serious consequences.

Parental perceptions on the obstacle domain show that some respondents have negative perceptions, it means some parents do not have obstacles in applying the GFCF diet to autistic children. One perceived obstacle is not having time to prepare glutenfree and casein-free foods. The results of this study are in accordance with the National Conference on Autism Spectrum Disorder (2006) which states that parents' obstacles were doing autism therapy, and costs for therapy. This study shows that respondents agree that the costs incurred for glutenfree and casein-free diet programs are quite high. According to the conference the existence of cost constraints can determine whether therapy continues or not (Wildman, 2006). Another potential obstacle is that parents cannot adhere to the GFCF diet in a compliant manner because of limited support from the environment. This was stated by Moore and Symons in 2011 in the USA and Ramdayanti in 2012 that the factors behind the implementation of the GFCF diet were support from the environment.

Almost all respondents stated that they found difficulties when traveling. This is in accordance with the research of Do Nascimento, Fiates, Dos Anjos, and Teixeira (2014) which states that a strong predictor that influences parents in adhering to a diet obediently is the difficulty when traveling. They find it difficult to find foods that do not contain gluten and casein, this is because parents do not know the types of food that can be used as supplies when going to travel. This difficulty causes parents to be unable to adhere to the GFCF diet obediently.

A positive perception of the GFCF diet would have an impact on parents' intention to implement it. This is supported by Bowker's research, D'Angelo, Hicks, and Wells (2011) which states that positive perceptions would increase the effectiveness of certain treatments in autistic children, whether parents will continue treatment or not. Therefore a positive perception of the GFCF diet is expected to encourage parents to increase their participation in implementing the GFCF diet. This positive perception must be supported by good knowledge, because the application of the GFCF diet without good knowledge would cause developmental problems in autistic children.

Increasing knowledge and maintaining a positive perception on parents regarding the GFCF dietdoby providing education regarding how to practise the right diet. Providing this education can be done through collaboration with nutritionists. Community nurses and nutritionists play a role in introducing how the correct GFCF diet from selection to food processing. One recommended method for providing education about the correct diet is to involve the school, and community nursing as partners. One program according to Wright et al (2012) is Coordinated School Health Programs (CSHP). The program integrates culturally sensitive schools by promoting health policies related to nutrition education programs, as well as the school environment which is a model of healthy food choices, and 
Ade Rosi: Knowledge and Perception of Parents Towards Diet in Children with Autism

supported by the provision of consultation services by health workers.

The problem is the community nursing program at the PHC has not yet been evenly distributed on improving health in SLB. The PHC could empower of School Health Enterprises (UKS) to improve the health of children with special needs. The school is intermediaries between community nurses and parents. School involvement in supporting the GFCF diet is indirectly a reminder for parents to continue their diet program at home. The obstacles in community nursing services does not prioritize the formation of UKS at the SLB as a forum for providing health information to improve health for teachers in the School. Therefore, the results of this study can be used as a community service program by health students or SWCs around the SLB at the junior or senior high school level to assist nursing. Community in forming UKS in SLB. Supporting the increase of parental knowledge regarding the GFCF diet are by conducting regular visits by health professionals, especially community nursing to gradually provide health education regarding the GFCF diet to parents. Giving material by the lecture method alone may not be enough for adulthood. Additional methods in the form of practice and consultation can be done so that the information provided is in two directions and easy to remember. Supported with learning media such as videos and leaflets / pocket books can be one way to make it easier for parents to choose and prepare food for autistic children. This educational intervention can involve other stakeholders such as the school and collaborate with nutritionists so that the material presented is broader and more detailed related to how to choose and prepare food for autistic children to be free of gluten and casein.

\section{Conclusion}

Several parents of autistic children in 3 SLBs in Bandung District had a positive perception of the Gluten Free Casein Free diet, although parental knowledge regarding the GFCF diet was in the insufficient category. This is probably because of respondents have not received more information about the
GFCF diet. Based on these results, health workers, especially community nurses and children are advised to make regular visits to provide health education related to the GFCF diet for parents of autistic children in SLB. This health education can be supported by using effective media such as videos and leaflets. The limitations in this study are that researchers only measure knowledge until the understanding stage $(\mathrm{C} 2)$ does not reach the stage of application (C3). Therefore, this study is expected to be the preliminary data for further research regarding parental knowledge and higher levels of the GFCF diet. This is also asses whether the diet that parents have done is correct or not, or whether parental compliance is low because parents do not know how correct diet

\section{References}

Apriana, Z. (2016). Pengaruh Pola Diet Gluten Free dan Casein Free terhadap Perilaku Anak Autis Di Makassar. Universitas Hasanuddin Makassar.

Artino, A. R. (2012). Academic self-efficacy: from educational theory to instructional practice. Perspectives on Medical Education, 1(2), 76-85. https://doi.org/10.1007/s40037012-0012-5.

Bowker, A., D'Angelo, N. M., Hicks, R., \& Wells, K. (2011). Treatments for autism: Parental choices and perceptions of change. Journal of Autism and Developmental Disorders, 41(10), 1373-1382. https://doi. org/10.1007/s 10803-010-1164-y.

Budiman, \& Riyanto, A. (2013). Kapita Selekta Kuesioner. (A. Suslia, Ed.). Jakarta: Salemba Medika.

Carpenter, C. J., \& Carpenter, C. J. (2016). A Meta-Analysis of the Effectiveness of Health Belief Model Variables in Predicting Behavior A Meta-Analysis of the Effectiveness of Health Belief Model Variables in Predicting Behavior. Health Communication, 0236(August), 661-669. https://doi.org/10.1 080/10410236.2010.521906. 
Ade Rosi: Knowledge and Perception of Parents Towards Diet in Children with Autism

Centers for Disease Control and Prevention. (2015). Estimated prevalence of Autism and other developmental disabilities following questionnaire changes in the 2014 National Health Interview Survey. National Health Statistics Reports, (87), 1-21.

Do Nascimento, A. B., Fiates, G. M. R., Dos Anjos, A., \& Teixeira, E. (2014). Gluten-free is not enough-perception and suggestions of celiac consumers. International Journal of Food Sciences and Nutrition, 65(4), 394398. https://doi.org/10.3109/09637486.2013 .879286 .

Efendi, I. F. (2014). Pengetahuan Ibu, Pola Asuh Makan dan Pola Konsumsi Gluten dan Kasein pada Anak Autis di Jakarta dan Bogor. Institut Pertanian Bogor.

Fadhli, A. (2010). Buku Pintar Kesehatan Anak. (N. Rosliyani, Ed.) (1st ed.). Yogyakarta: Pustaka Anggrek.

Glanz, K., Rimer, B. K., \& Viswanath, K. (2008). Health Behaviour and Health Education (4th ed.). San Fransisco: John Wiley \& Sons.

Glanz, K., Rimer, B. K., \& Viswanath, K. (2015). Health Behavior: Theory, Research, and Practice Jossey-Bass Public Health (5th ed.). San Fransisco: John Wiley \& Sons.

Greene, J. S. N., Rathus, S. A., \& Beverly. (2003). Psikologi Abnormal (5th ed.). Jakarta: Erlangga.

Hurwitz, S. (2013). The Gluten-Free, Casein-Free Diet and Autism: Limited Return on Family Investment. Journal of Early Intervention, 35(1), 3-19. https://doi. org/10.1177/1053815113484807.

Kawicka, A., \& Regulska-Ilow, B. (2013). How nutritional status, diet and dietary supplements can affect autism. A review. Roczniki Państwowego Zakładu Higieny, 64(1), 1-12.

Kementerian Kesehatan Republik Indonesia. (2012). Kemenkes Peringati Hari Autis Internasional, 2-3.
Koka, E. M. (2011). Perilaku Ibu tentang Pemberian Makan dan Status Gizi Anak Autisme di Kota Binjai. Universitas Sumatera Utara. Retrieved from http://repository.usu. ac.id/handle/123456789/27646.

Marí-Bauset, S., Llopis-González, A., Zazpe, I., Marí-Sanchis, A., \& Suárez-Varela, M. M. (2016). Nutritional Impact of a Gluten-Free Casein-Free Diet in Children with Autism Spectrum Disorder. Journal of Autism and Developmental Disorders, 46(2), 673-684. https://doi.org/10.1007/s 10803-015-2582-7.

McKinley, C. J., \& Wright, P. J. (2014). Informational social support and online health information seeking: Examining the association between factors contributing to healthy eating behavior. Computers in Human Behavior, 37, 107-116. https://doi. org/10.1016/j.chb.2014.04.023.

Moore, T. R. (2010). Predictors of adherence to treatment by parents in a behavioral intervention curriculum for children with autism spectrum disorders. ProQuest Dissertations and Theses, 71(7-A), 2345.

Mubarak, W. I., Cahyatin, N., Rozikin, K., \& Supradi. (2007). Promosi Kesehatan: Sebuah Pengantar Proses Belajar Mengajar dalam Pendidikan (1st ed.). Yogyakarta: Graha Ilmu.

Murdiyanta, C. C., Ramani, A., \& Sulistiyani. (2015). Faktor Ibu Dalam Pemilihan Makanan Pada Anak Autis Di Sekolah Luar Biasa Arya Satya Hati Kota Pasuruan.

Mutianingrum, A. (2013). Hubungan Tingkat Pengetahuan Ibu dengan Pemberian Diet Bebas Gluten, Kasein dan Status Gizi pada Anak Autis. Universitas Gajah Mada.

Niland, B., \& Cash, B. D. (2018). Health benefits and adverse effects of a glutenfree diet in non-celiac disease patients. Gastroenterology and Hepatology, 14(2), 82-91.

Notoatmodjo, S. (2012). Metodologi Penelitian Kesehatan (2nd ed.). Jakarta: Rineka Cipta. 
Ade Rosi: Knowledge and Perception of Parents Towards Diet in Children with Autism

Nugraheni, S. (2008). Efektivitas Diet Bebas Gluten Bebas Casein terhadap Perubahan Perilaku Anak Autis. Universitas Gajah Mada.

Nursalam. (2013). Metodologi Penelitian Ilmu Keperawatan : Pendekatan Praktis (3rd ed.). Jakarta: Salemba Medika.

Rahmah, J., Diani, N., \& Rachmawati, K. (2015). Kepatuhan Orang Tua Tentang Diet Gluten Free Dan Casein Free Dengan Perilaku Anak Autis. DK Diet Gluten Free Dan Casein Free, 3(2), 16-25.

Ratnawati. (2003). Penatalaksanaan Holistik Autisme : Leaky Gut pada Autisme.

Ratnawati, H. (2013). Leaky Gut pada Autisme. Pusat Informasi Dan Penerbitan Bagian Ilmu Penyakit Dalam Fakultas Kedokteran Universitas Indonesia.

Sadeghi, R., Sedaghat, M. M., \& Sha Ahmadi, F. (2014). Comparison of the effect of lecture and blended teaching methods on students' learning and satisfaction. Journal of Advances in Medical Education \& Professionalism, 2(4), 146-150.

Sari, Y. K., \& Sari, D. (2015). Hubungan Peran Orangtua terhadap Kepatuhan Terapi Diet Gluten Free Casein Free pada Anak Autisme di SLB Khusus Autis Al-Ikhlas Bukittinggi. Stikes Prima Nusantara Bukittinggi, 6(1).

Sofia, A. D. (2012). Kepatuhan Orang Tua Dalam Menerapkan Terapi Diet Gluten Free Casein Free Pada Anak Penyandang Autisme Di Yayasan Pelita Hafizh Dan Slbn Cileunyi Bandung. Students E-Journal, 1(1), 33.

Solish, A., \& Perry, A. (2008). Parents' involvement in their children's behavioral intervention programs: Parent and therapist perspectives. Research in Autism Spectrum Disorders, 2(4), 728-738. https://doi. org/10.1016/j.rasd.2008.03.001.

Steiner, A. M., \& Koegel, L. K. (2011). Issues and Theoretical Constructs Regarding Parent Education for Autism Spectrum Disorders Issues and Theoretical Constructs Regarding Parent Education. Journal of Autism and Developmental Disorders, 42(January 2016), 1218-1227. https://doi.org/10.1007/s10803011-1194-0.

Stretcher, V., \& Rosenstock, I. M. (1997). The Health Belief Model. Health Behavior and Health Education: Theory, Research and Practice, 31-36.

Sugiyono. (2010). Metode Penelitian Kuantitatif Kualitatif dan $R \& D$. Bandung: Alfabeta.

Whiteley, P., Haracopos, D., Knivsberg, A.M., Reichelt, K. L., Parlar, S., Jacobsen, J., ... Shattock, P. (2010). The ScanBrit randomised, controlled, single-blind study of a gluten- and casein-free dietary intervention for children with autism spectrum disorders. Nutritional Neuroscience, 13(2), 87-100. https://doi.org/ $10.1179 / 147683010 X 12611460763922$.

Whiteley, P., Shattock, P., Knivsberg, A.-M., Seim, A., Reichelt, K. L., Todd, L., ... Hooper, M. (2013). Gluten- and casein-free dietary intervention for autism spectrum conditions. Frontiers in Human Neuroscience, 6(January), 1-8. https://doi. org/10.3389/fnhum.2012.00344.

Wildman, H. E. (2006). ASA's 37th National Conference on Autism Spectrum Disorders : The Health Belief Model and Prediction of Parents Choices of Autism Treatment. Clinical Psychologist in the Department of Developmental and Rehabilitation Pediatrics, 554. Retrieved from https://asa.confex.com/ asa/2006/techprogram/S2189.HTM.

Wright, K., Norris, K., Newman Giger, J., \& Suro, Z. (2012). Improving Healthy Dietary Behaviors, Nutrition Knowledge, and SelfEfficacy among Underserved School Children with Parent and Community Involvement. Childhood Obesity, 8(4), 347-356. https:// doi.org/10.1089/chi.2012.0045. 